\title{
Meningkatkan Pemahaman Analytical Exposition Melalui Metode Think Pair and Share
}

\author{
LINA MARTINI \\ Tenaga Pengajar pada Dinas Pendidikan Kabupaten Kampar \\ SMP Negeri 2 Tambang \\ Email: linamartini@yahoo.com
}

\begin{abstract}
The ability to improve learning outcomes becomes a target in learning, a learner needs to study seriously and always seriously understand the various subject matter. So far in learning analytical exposition of a learner is still not optimal to achieve it. Through classroom action research by applying think pair and share action and analyzed descriptively, hence obtained result that applying of think pair and share action method can improve ability of analytical exposition in learners.
\end{abstract}

Keywords: think pair and share model, analytical exposition.

Model pembelajaran merupakan salah satu penyebab yang dapat mempengaruhi minat belajar kepada peserta didik, selama ini model pembelajaran yang dilakukan di sekolah-sekolah bersifat konvensional (siswa hanya mendengarkan saja apa yang dijelaskan oleh guru). Peran guru pada model konvensional sangat dominan atau aktif sedangkan peserta didik bersifat pasif sehingga terkadang hanya berdampak kepada kebingungan siswa dalam menerima pelajaran dan bukannya siswa mengerti dan bahkan bisa memahami apa yang diajarkan gurunya.

$$
\text { Dalam kegiatan belajar }
$$
mengajar, jelas yang menjadi sasaran transfer ilmu pengetahuan adalah siswa, dimana siswa merupakan target dan indikator pencapaian target adalah sejauhmana siswa sudah mendapatkan apa yang telah diberikan gurunya. Semakin baik cara atau metode pengajaran yang diterapkan oleh gurunya maka semakin baik pula hasil yang diterima oleh siswa di kelas.

Keaktifan siswa dalam belajar sudah menjadi model terbaru dalam dunia pendidikan, dimana siswa lebih aktif dalam mendapatkan ilmu pengetahuan dibandingkan dengan gurunya. Guru bertindak sebagai perantara ilmu pengetahuan dan pihak yang memberikan penjelasan kepada siswa dan memberikan motivasi belajar kepada siswa agar siswa dengan sadar senang belajar dan tertarik untuk mendapatkan apa yang diinginkannya.

Salah satu model pembelajaran yang bersifat demikian adalah model pembelajaran kooperatif. Dalam model pembelajaran kooperatif, siswa dituntut bekerja dalam kelompok kecil yang heterogen untuk memecahkan suatu masalah. Karena dalam pembelajaran kooperatif keberhasilan kelompok sangat diperhatikan, maka siswa yang pandai ikut membantu siswa yang lemah dalam kelompok masing-masing sehingga siswa yang pandai dapat mengembangkan kemampuan dan ketrampilan yang dimilikinya dan sebaliknya siswa yang lemah akan terbantu dalam memahami permasalahan yang ada. Dengan kata lain, kemampuan anggota kelompok sangat dipengaruhi oleh keaktifan anggota kelompok tersebut dengan melakukan apa saja dalam keberhasilan kelompok.

Model ini dapat diterapkan pada mata pelajaran bahasa inggris, karena model ini bertujuan agar adanya kerjasama antara guru dan siswa dalam proses pembelajaran sehingga materi pembelajaran yang diajarkan dapat mudah diserap dan dikembangkan oleh siswa 
dalam belajar. Namun dalam pelajaran bahasa inggris khususnya pada sub bahasan Analytical exposition dengan kompetensi dasar adalah setelah siswa mempelajarinya siswa dapat memahami kondisi analisis teks masih belum sesuai dengan kondisi yang terjadi. Dimana dari hasil pre tes yang dilakukan kepada siswa kelas XI. SMA N 2 Kampar Kiri Hilir, KKM yang diharapkan kepada siswa mencapai angka 81 belum tercapai sepenuhnya yakni hanya mencapai rata-rata $58,1 \%$.

Selain itu, sikap mental siswa dalam mengikuti materi pelajaran juga masih belum memuaskan, dimana siswa masih belum fokus mengikuti materi pelajaran dan masih ribut di kelas sehingga terkadang konsentrasi guru dalam mengajar menjadi terganggu. Selain itu siswa masih kurang aktif dalam menanggapi berbagai bentuk pertanyaan yang diajukan oleh guru. Memang diakui bahwa selama ini materi yang diberikan berdasarkan metode pembelajaran ceramah sehingga ada kesan siswa bosan dengan ceramah yang diberikan oleh guru di depan kelas.

Berdasarkan pada uraian di atas, maka pada kesempatan ini saya tertarik melakukan penelitian tindakan kelas dengan menerapkan metode pembelajaran think pair square dalam rangka meningkatkan hasil belajar siswa dalam belajar mata pelajaran bahasa inggris khususnya sub materi Analytical exposition Pada penelitian ini definisi operasionalnya adalah:Hasil belajar capaian yang diperoleh siswa baik berupa hard skill dalam kemampuan secara teknis dalam mempelajari Analytical exposition dan juga soft skill dalam melatih sikap prilaku dalam masa belajar dan memahami apa yang dipelajarinya. Teknik think pair and share merupakan teknik pembelajaran dengan memberikan memberikan kesempatan kepada siswa untuk mendiskusikan gagasan mereka dan memberikan suatu pengertian bagu mereka untuk melihat cara lain dalam penyelesaian masalah. Jika seorang siswa dapat menyelesaikan masalah tersebut yaitu dengan menjelaskan cara menjawabnya dan jika permasalahan yang diajukan tidak memiliki suatu jawaban yang benar, maka dua pasangan siswa dapat mengkombinasikan hasil mereka dan membentuk suatu jawaban yang lebih menyeluruh.

Beberapa penelitian terdahulu memberikan kajiannya dan menjadi rujukan dalam penelitian ini antara lain menurut: Susanti, R. (2002) penguasaan kosa kata bahasa Inggris siswa berbanding lurus dengan kemampuan membaca bahasa Inggris siswa. Siswa yang memiliki penguasaan kosa kata tinggi, tinggi pula kemampuan membaca bahasa Inggrisnya. Hal yang sama terjadi pada siswa yang rendah penguasaan kosa katanya, kemampuan membaca bahasa Inggrisnya rendah pula.

Selain itu juga menurut Suherman, E. (2008) Tugas utama guru adalah membelajarkan siswa, yaitu mengkondisikan siswa agar belajar aktif sehingga potensi dirinya (kognitif, afektif, dan konatif) dapat berkembang dengan maksimal. Dengan belajar aktif, melalui partisipasi dalam setiap kegiatan pembelajaran, akan terlatih dan terbentuk kompetensi yaitu kemampuan siswa untuk melakukan sesuatu yang sifatnya positif yang pada akhirnya akan membentuk life skill sebagai bekal hidup dan penghidupannya. Agar hal tersebut di atas dapat terwujud, guru seyogianya mengetahui bagaimana cara siswa belajar dan menguasai berbagai cara membelajarkan siswa. Model belajar akan membahas bagaimana cara siswa belajar, sedangkan model pembelajaran akan membahas tentang bagaimana cara membelajarkan siswa dengan berbagai variasinya sehingga terhindar dari rasa bosan dan tercipta suasana belajar yang nyaman dan menyenangkan.

Kemudian Latief, H. A. (2016) berpendapat bahwa Penelitian Tindakan Kelas merupakan media untuk peningkatan kemampuan profesional guru dan untuk peningkatan ke berhasilan belajar siswa. Dalam PTK, guru melakukan evaluasi

$$
\text { p.ISSN: 2407-800X e.ISSN: 2541-4356 }
$$


terhadap kegiatan mengajarnya dan kemudian melakukan perbaikan atas dasar hasil evaluasi tersebut. Seringkali perubahan strategi pembelajaran yang ditemukan oleh guru lebih mudah menyebar kepada guruguru lain (bottom up) dibanding dengan perubahan yang ditawarkan oleh atasan (top down).

Kemudian Novitasari, D. R. (2010) Media Pembelajaran Bahasa Inggris untuk Kelas 1 Sekolah Dasar Negeri 15 Sragen dapat meningkatkan kualitas belajar peserta didik Kelas. Usman, A. H. (2015) the implementation of the strategy was continued cycle 2 by revising the plan. The students' average score in cycle 2 achieved 81.68 and classroom atmospheres were "mid." It means that the results in cycle 2 met the criteria of success and judged as successful. So, it can be stated that the think-pair-share strategy was effective to be implemented at STAIN Ternate in order to improve the students' speaking ability.

Dari beberapa pendapat tersebut di atas, penulis tertarik menerapkan metode metode think pair share dalam upaya meningkatkan kemampuan berbahasa inggris siswa.

\section{METODE}

Jenis penelitian yang digunakan dalam penelitian ini adalah menggunakan penelitian tindakan karena penelitian tindakan kelas adalah merupakan penelitian yang lebih sesuai dengan tugas pokok dan fungsi guru, meningkatkan kualitas pembelajaran, meningkatkan kualitas siswa, serta mencapai tujuan pembelajaran atau pendidikan.

Subyek dalam penelitian ini ditentukaan berdasarkan pertimbanganpertimbangan tertentu. Pertimbangan yang dimaksudkan di sini adalah pertimbangan keterlaksanaan pembelajaran mempergunakan think pair square dalam pembelajaran materi Analytical exposition. Dalam penelitian ini yang menjadi subyek penelitian adalah siswa kelas XI SMA N 2 Tambang.
Metode pengumpulan data pada penelitian ini adalah observasi, tes, wawancara dan catatan lapangan. Teknik analisis data yang dipergunakan adalah reduksi data, penyajian data, penarikan simpulan, serta verifikasi refleksi.

\section{HASIL}

Hasil penelitian ini terbagi menjadi dua siklus, yang dimulai dari refleksi awal. Refleksi awal dilaksanakaan dengan melakukan pengamatan pendahuluan untuk mengetahui kondisi awal dilakukan oleh pengamat kelas, yakni rekan sejawat. Hasil refleksi awal dipergunakan untuk menetapkan dan merumuskan rencana tindakan yaitu menyusun strategi awal pembelajaran.

Berdasarkan hasil pengamatan pendahuluan ditemukan bahwa selama pembelajaran berlangsung sebagian siswa kurang memiliki sikap mental siswa dalam mengikuti materi pelajaran juga masih belum memuaskan, dimana siswa masih belum fokus mengikuti materi pelajaran dan masih ribut di kelas sehingga terkadang konsentrasi guru dalam mengajar menjadi terganggu. Selain itu siswa masih kurang aktif dalam menanggapi berbagai bentuk pertanyaan yang diajukan oleh guru. Memang diakui bahwa selama ini materi yang diberikan berdasarkan metode pembelajaran ceramah sehingga ada kesan siswa bosan dengan ceramah yang diberikan oleh guru di depan kelas.

Kegiatan pembelajaran Analytical exposition dapat disajikan dengan menggunakan strategi atau pendekatan dan penggunaan think pair square dan dapat mengatasi permasalahan tersebut, yaitu metode pembelajaran pari think square. Akhirnya kegiatan pembelajaran dapat berjalan dengan wajar, motivasi belajar siswa meningkat, dan pada akhirnya pestasi belajar siswa meningkat.

Berdasarkan pengamatan awal yang dilakukan oleh guru yang bertindak sebagai peneliti, pada saat berlangsungnya proses pembelajaran diperoleh data kondisi dan permasalahan pembelajaran yang terjadi 
pada siswa kelas XI. SMA N 2 Tambang kurang mampu mengingat pelajaran Analytical exposition sehingga siswa memiliki hasil belajar yang rendah.

Berdasarkan kondisi yang ada, maka peneliti merencanakan pembelajaran dengan think pair square, agar siswa mampu mengingat yang terjadi pada Analytical exposition dari penjelasan yang diberikan oleh guru di depan kelas dan dari buku pelajaran bahasa inggris kelas XI, sehingga prestasi belajarnya meningkat.

Pembelajaran dengan think pair square menekankan pada kegiatan aktif siswa, karena semua siswa terlibat dalam pembelajaran. Guru membagi siswa dalam kelompok berempat dan memberikan tugas kepada semua kelompok, kemudian setiap siswa memikirkan dan mengerjakan tugas tersebut sendiri. Siswa berpasangan dengan salah satu rekan dalam kelompok dan berdiskusi dengan pasangannya dan selanjutnya kedua pasangan bertemu kembali dalam kelompok berempat. Siswa mempunyai kesempatan untuk membagikan hasil kerjanya kepada kelompok berempat.

belum memahami secara baik metode yang diterapkan kepadanya. Hasil belajar siswa pada siklus pertama tampak pada tabel di bawah ini:

Tabel 1 : Siklus 1

\begin{tabular}{|l|l|l|}
\hline Rata-Rata & 81 & Tuntas \\
\hline Tuntas & 18 & $58.1 \%$ \\
\hline Tidak tuntas & 13 & $41.9 \%$ \\
\hline & 31 & $100.0 \%$ \\
\hline
\end{tabular}

Berdasarkan pengamatan, siswa dalam pembelajaran pada siklus pertama prestasi belajar siswa rata-rata 81 dan pada siklus I yang sudah tuntas ada 18 siswa $(58,1 \%)$ dengan rata-rata capaian 81 .

Tabel 2 : Siklus 2

\begin{tabular}{|l|c|c|}
\hline Rata-Rata & 86 & Tuntas \\
\hline Tuntas & 25 & $80.6 \%$ \\
\hline Tidak tuntas & 6 & $19.4 \%$ \\
\hline & 31 & $100.0 \%$ \\
\hline
\end{tabular}

Berdasarkan pengamatan, siswa dalam pembelajaran pada siklus kedua prestasi belajar siswa rata-rata 86 dan pada siklus kedua yang tuntas ada 25 siswa $(80,6 \%)$ yang tidak tuntas ada 6 siswa $(19,4 \%)$.

Tabel 3 : Siklus 3

\begin{tabular}{|l|c|c|}
\hline Rata-Rata & 91 & Tuntas \\
\hline Tuntas & 28 & $90.3 \%$ \\
\hline Tidak tuntas & 3 & $9.7 \%$ \\
\hline & 31 & $100.0 \%$ \\
\hline
\end{tabular}

Berdasarkan pengamatan, siswa dalam pembelajaran pada siklus ketiga prestasi belajar siswa rata-rata 91 dan pada siklus kedua yang tuntas ada 28 siswa $(90,3 \%)$.

\section{PEMBAHASAN}

Dalam pelaksanaan penelitian tindakan kelas pada materi Analytical exposition siswa yang diamati meliputi tanggapan siswa dalam memperhatikan penjelasan umum tentang metode pair think and share, keterlibatan siswa dalam memikirkan jawaban, keberanian siswa dalam mencari pasangan dalam kelompok yang telah ditentukan, keberanian siswa dalam mendeskrekonomiikan Analytical exposition dan kecepatan siswa dalam menyelesaikan pertanyaan.

Berdasarkan hasil pengamatan menunjukkan bahwa selama kegiatan belajar mengajar pada siklus pertama tanggapan siswa dalam memperhatikan penjelasan umum tentang metode pair think and share dengan kategori cukup, keterlibatan siswa dalam memikirkan jawaban juga dalam kategori baik, keberanian siswa dalam mencari rekan yang cocok juga baik, keberanian siswa dalam memahami analytical exposition masih cukup dan kecepatan siswa dalam menyelesaikan pertanyaan juga cukup.

Selama kegiatan belajar mengajar pada siklus kedua tanggapan siswa dalam memperhatikan penjelasan umum tentang metode pair think and share dengan kategori baik, keterlibatan siswa dalam memikirkan jawaban juga dalam kategori baik, keberanian siswa dalam mencari rekan yang cocok juga cukup, keberanian siswa 
dalam mendeskrekonomiikan Analytical exposition baik dan kecepatan siswa dalam menyelesaikan pertanyaan juga baik.

Berdasarkan hasil pengamatan menunjukkan bahwa selama kegiatan belajar mengajar aktivitas guru selama siklus pertama dan kedua yang diamati antara lain: (a) pembukaan yang meliputi motivasi dan persepsi berkriteria baik, (b) Perangkat pembelajaran yang meliputi penguasaan materi, sistematika penyampaian tugas pada siswa, kejelasan dalam pemberian konsep, kesesuaian metode yang dipergunakan, pengelolaan kelas, penggunaan papan tulis, komunikasi yang ditimbulkan, serta ada tidaknya penghargaan kepada siswa berkriteria cukup, (c) Penampilan guru yang meliputi suara guru harus dapat didengar dengan jelas berkriteria baik, guru berpakaian bersih rapi dan sopan berkriteria baik, mobilitas guru berkriteria baik, serta ekspresi guru berkriteria baik, (d) Penutup yang meliputi rangkuman materi yang disampaikan guru, postes, serta cara menutup pembelajaran berkriteria baik.

\section{SIMPULAN}

Berdasarkan hasil penelitian tindakan kelas pada kelas XI pada mata pelajaran bahasa inggris sub bahasan Analytical exposition dapat disimpulkan. Setelah penerapan metode pair think and share kepada siswa terbukti bahwa berdasarkan data pengamatan terus mengalami peningkatan.

Melalui penerapan metode pair think and share dengan membagi siswa dalam kelompok berempat dan memberikan tugas kepada semua kelompok dan setiap siswa memikirkan dan mengerjakan tugas tersebut sendiri. Lalu siswa berpasangan dengan salah satu rekan dalam kelompok dan berdiskusi dengan pasangannya. Kemudian kedua pasangan bertemu kembali dalam kelompok berempat dan siswa mempunyai kesempatan untuk membagikan hasil kerjanya kepada kelompok berempat berhasil meningkatkan hasil belajar siswa.

\section{DAFTAR RUJUKAN}

Arikunto, Suharsimi. 2005. Dasar-Dasar Evaluasi Pendidikan. Jakarta: Bumi Aksara.

Indah Wati, 2013, Item Tes Think pair square

Anita Lee, 2002, Cooperative Learning, PT. Gramedia Widiasarana, Jakarta.

Susanti, R. (2002). Penguasaan kosakata dan kemampuan membaca bahasa inggris. Jurnal pendidikan penabur, 1(1), 87-93.

Suherman, E. (2008). Model belajar dan pembelajaran berorientasi kompetensi siswa. EDUCARE, 5(2).

Latief, H. A. (2016). Penelitian Tindakan Kelas Pembelajaran Bahasa Inggris. Jurnal Ilmu Pendidikan, 10(2).

Novitasari, D. R. (2010). Pembangunan Media Pembelajaran Bahasa Inggris Untuk Siswa Kelas 1 Pada Sekolah Dasar Negeri 15 Sragen. Speed-Sentra Penelitian Engineering dan Edukasi, 2(1).

Usman, A. H. (2015). Using the think-pairshare strategy to improve students' speaking ability at Stain Ternate. Journal of Education and Practice, 6(10), 37-45. 